\title{
THERMOREGULATORY RESPONSES OF SHEEP TO STARVATION AND HEAT STRESS CONDITIONS
}

\author{
T.M.M. Abdel Khalek \\ Animal Production Research Institute, Dokki, Giza, Egypt
}

\section{SUMMARY}

The present study was carried out at Sakha Animal Production Experimental Station belonging to Animal Production Research Institute. The experiment was conducted under thermoneutral conditions (TNZ) in winter $(\mathrm{THI}<74)$ and during moderate heat stress (MHS, THI 74 - <88) in summer season on 9 and 6 Ossimi rams, respectively. Body weight, thermoregulatory parameters and blood parameters were determined at the start of the experiment and after 48 and 96 hrs of starvation in each experiment. Ambient temperature (Ta), relative humidity ( $\mathrm{RH} \%)$ and Temperature-Humidity Index (THI) were measured simultaneously during the experiment.

Under TNZ, starvation had no significant effect on rectal temperature (RT), due to a significant and insignificant reduction in heat production (HP) and evaporative cooling (minute ventilation, $M V$ ), respectively. While under MHS, starvation reduced the effect of heat stress on $R T$ by decreasing $M V$ and respiration rate $(R R)$, while, $H P$ remained almost unchanged. Under TNZ, starvation caused an insignificant and significant decrease in plasma total cholesterol (Tcho.) and total lipids (Tl), respectively. Meanwhile under MHS, starvation had no significant effect on plasma Tcho. and Tl concentrations.

Before starvation, moderate heat stress caused a significant increase in $R T$; meanwhile, respiratory evaporation (MV) and heat production (HP) were lower than that in the TNZ. Moderate heat stress (MHS) did not affect significantly blood hematocrit (Ht) and plasma proteins (plasma total proteins (Tp), albumin (Alb) and globulin (Gl)) while it increased significantly plasma glucose concentration.

It could be concluded that starved sheep can tolerate moderate heat stress by decreasing evaporative cooling; meanwhile normal fed sheep depends on heat storage to tolerate moderate heat stress.

Keywords: Sheep, starvation, heat stress, thermoregulation, metabolic rate

\section{INTRODUCTION}

Ossimi sheep is an Egyptian native fat-tailed breed. Salem et al. (1982) reported that the Egyptian native fat-tailed sheep were shown to be more heat tolerant than the European breeds as fat-tailed sheep have lower rectal temperature and respiration rate than the European breeds under the same management and environmental conditions. Devendra (1982) stated that $43.3 \%$ of the total world populations of sheep are presented in tropical and subtropical regions. Sheep plays underestimated but 
valuable role in the supply of dietary animal proteins and also socioeconomic status of several million small farmers, peasants and landless agricultural laborers.

Under Egyptian conditions, sheep, goats and camels are the main species for animal production in the desert areas. The usual watering and feeding in the desert conditions varies from one day to many days depending on the season, availability of water, feed and distance traveled between watering points. Under these conditions animals are faced with two physiological problems; namely, obtaining sufficient feed and water, and regulating their body temperature. The lack of feed and water would impose starvation and dehydration which affects productivity (body weight, fertility and milk production), thermoregulation (physiological reactions) and blood chemistry and metabolites (More et al., 1983).

In tropical and subtropical regions animal are subjected to heat stress due to high environmental temperature and relative humidity during hot season. Heat stress affects significantly the heat balance of homoeothermic animals and the main thermoregulatory mechanisms are the reduction in heat production and increase in heat loss (Johnson et al., 2003). Khalifa et al. (1987), Khalifa et al. (2002), Srikandakumar et al. (2003) and Al-Haidary (2004) found that heat stress caused a significantly increase in rectal temperature and respiration rate of sheep and the effect was more pronounced in less adapted breeds (Srikandakumar et al. 2003). Mitlöhnera et al. (2001) stated that during heat stress the coping strategy of cattle is to decrease metabolic heat production by lowering feed intake, which adversely affects productivity. Many authors reported that heat production decreased under heat stress (Luiting et al., 1985 and Berman, 2003).

Bell et al. (1983) revealed that during heat stress, panting animals increase respiratory heat loss by increasing minute ventilation and when the heat stress is severe, the increase in minute ventilation includes an increase in alveolar ventilation and consequently, arterial $\mathrm{CO}_{2}$ tension $\left(\mathrm{PaCO}_{2}\right)$ declines resulting in a respiratory alkalosis.

Regarding the effect of starvation on thermoregulation, Brockway et al. (1965) found that starvation for 3 to 4 days decreased total heat loss, sensible heat loss and respiratory and skin evaporation of Cheviot sheep. Also, it has been found that fasting or starvation decreased $\mathrm{VO}_{2}, \mathrm{VCO}_{2}$, RQ and heat production (Blaxter and Waiman, 1966, Bennet, 1972, Kelly et al., 1993 and Khalifa et al., 2003).

The objectives of the preset study were to determine the influence of feed deprivation under thermoneutral and moderate heat stress conditions on thermoregulation of native Egyptian sheep adapted to heat stress as well as to investigate the thermoregulatory mechanisms of normal and starved sheep to tolerate moderate heat stress under Egyptian conditions.

\section{MATERIALS AND METHODS}

The present study was carried out at Sakha Animal Production Experimental Station belonging to Animal Production Research Institute. Fifteen unshorn (wool length more than $5 \mathrm{~cm}$ ) Ossimi Rams (9 in winter season and 6 in summer season) were selected randomly and used in these studies. They were 2.5 to 3.0 years of age. All animals were fed concentrate and hay ration according to their requirements (NRC, 1985). The feed concentrate mixture contained 12\% crude protein and 50\% starch value. It was consisted of $35 \%$ corticated cotton seed meal, $22 \%$ corn, $33 \%$ 
wheat bran, $4 \%$ rice bran, $3 \%$ molasses, $2 \%$ lime stone and $1 \%$ salt. Fresh tap water was available ad lib. Animals were kept indoors in metabolic cages during the experimental period to determine nitrogen balance. Thermoregulatory and blood parameters were determined immediately before ( 0 time) and after 48 and $96 \mathrm{hrs}$ of starvation.

Ambient temperature (Ta) and relative humidity ( $\mathrm{RH} \%$ ) were recorded simultaneously while measuring the physiological responses. The TemperatureHumidity Index (THI) was calculated from Ta and RH according to Thom (1959) converted to ${ }^{\circ} \mathrm{C}$ as follows:

$\mathrm{THI}=9 / 5 *((\mathrm{~T} * 17.778)-(0.55-(0.55 * \mathrm{RH} / 100)) *(\mathrm{~T}-14.444))$.

Where:

$\mathrm{T}=$ Dry bulb temperature in ${ }^{\circ} \mathrm{C}$.

$\mathrm{RH}=$ Relative humidity as \%.

The experiment was carried out under thermoneutral conditions $(\mathrm{THI}<72)$ in winter (according to Fuquay (1981) and Khalifa (2005) and during mild to moderate heat stress (THI $76-78.5$ ) in summer season (moderate heat stress according to Fuquay (1981) and mild to moderate heat stress according to Khalifa (2005).

In both seasons, the physiological parameters were measured every $48 \mathrm{hrs}$. at midday of the highest Ta from 12.00 to 14.00 . Rectal temperature (RT, ${ }^{\circ} \mathrm{C}$ ) was determined using a clinical thermometer $\left(0.1^{\circ} \mathrm{C}\right.$ accuracy inserted $5 \mathrm{~cm}$ in the rectal for $1 \mathrm{~min}$.). Skin temperature $\left(\mathrm{ST},{ }^{\circ} \mathrm{C}\right)$ and ear temperature $\left(\mathrm{ET},{ }^{\circ} \mathrm{C}\right)$ were measured using the Minolta/Land Cyclops Compac 3, a portable infrared thermometer $(0.95 \%$ error and $0.1{ }^{\circ} \mathrm{C}$ accuracy). Respiration rate (RR) was determined by counting the flank movements in one minute. Respiratory minute volume (MV as $1 /$ minute) was measured by Dry Gas Meter. Tidal volume (TV) was calculated by dividing MV/RR. Heat production (HP) (measured as fasting metabolic rate, $\mathrm{kcal} / \mathrm{BW}^{0.75}$ per day) was calculated using the equation of Brouwer (1965). The measurement of oxygen consumption $\left(\mathrm{VO}_{2}\right)$ and carbon dioxide production $\left(\mathrm{VCO}_{2}\right)$ were made using the open-circuit technique according to Yousef and Dill (1969). Oxygen consumption was calculated from the oxygen deficit in expired air using oxygen analyzer (Servomex 570). The rate of carbon dioxide production was calculated from the $\mathrm{CO}_{2}$ deficit in expired air obtained from infrared Gas Analyzer (Model-AR-411). Calculation of $\%$ true $\mathrm{VO}_{2}, \mathrm{VCO}_{2}$ and volume $\mathrm{VO}_{2}$ consumption and $\mathrm{O}_{2}$ and $\mathrm{CO}_{2}$ production and Respiratory Quotient (RQ) were done using the equations of Consolazio et al. (1963) where $\mathrm{RQ}=$ volume of $\mathrm{CO}_{2}$ produced/volume of $\mathrm{O}_{2}$ consumed.

Blood samples were collected from the jugular vein in heparinized tubes. Hemoglobin concentration $(\mathrm{Hb}, \mathrm{g} / \mathrm{l})$ was determined by colorimetric methods using hemoglobin kits (Drabkins reagent) and hematocrite value ( $\mathrm{Ht}, \%)$ using microhematocrite technique. Plasma total protein (TP, $\mathrm{mg} / \mathrm{dl}$ ) and plasma albumin (Alb, mg/dl) concentrations were determined using the kits of the Egyptian American Co. Plasma globulin (Gl, $\mathrm{mg} / \mathrm{dl}$ ) was calculated by subtraction. Glucose concentration (Glu, mg/dl), total cholesterol (Tcho, mg/dl), and total lipids (TL, g/dl) were measured by colorimetric method using Sentinal kits.

The statistical analysis of data was carried out using SAS program (SAS, 1990). Proc GLM of SAS (two way analysis of variance with one way repeated measurement) was used to test the effect of heat stress, starvation and their interaction. To test the effect of interaction, analysis of variance and least square 
means (Proc. LS means of SAS) were used to test the effect of starvation within each temperature group and Student $t$ test (Proc MEANS of SAS) was used to test the effect of temperature within each starvation interval.

\section{RESULTS AND DISCUSSION}

Meteorological data (Table, 1) reveal that mean ambient temperature (Ta) and relative humidity during the experimental period ranged between 23.7 to $26.2{ }^{\circ} \mathrm{C}$ and 36 to $40 \%$ in the first experiment (in winter) and 27.9 to $33.7{ }^{\circ} \mathrm{C}$ and 26 to $54 \%$ in the second experiment (in summer), respectively. The mean THI ranged between 68.4 to 71.9 and 76 to 78.5 in the first and second experiments, respectively. According to Fuquay (1981) and Khalifa (2005) sheep were under the thermoneutral zone range in winter and mild to moderate heat stress in summer.

Table 1. Ambient temperature $\left(\mathrm{AT}^{\circ} \mathrm{c}\right)$, relative humidity (RH \%) and Temperature-Humidity Index (THI) during the experiment period

\begin{tabular}{lcccccc}
\hline \multirow{2}{*}{ Parameter } & \multicolumn{2}{c}{ Thermoneutral zone (TNZ) } & \multicolumn{3}{c}{ Moderate heat stress (MHS) } \\
\cline { 2 - 7 } & 0 time & 48 hrs & 96 hrs & 0 time & 48 hrs & 96 hrs \\
\hline AT & 24.1 & 26.7 & 23.4 & 33.7 & 27.9 & 30.0 \\
RH & 40.0 & 38.0 & 35.9 & 25.7 & 54.0 & 39.8 \\
THI & 69.7 & 71.9 & 68.4 & 78.5 & 76.0 & 76.7 \\
\hline
\end{tabular}

Fuquay (1981) stated that a THI of 72 and below is considered as no heat stress, 73-77 as mild heat stress, $78-89$ as moderate and above 90 as severe, while Khalifa (2005), based on changes in body temperature, heat production and heat loss of sheep, reported that the comfort zone ranged between $20-25{ }^{\circ} \mathrm{C}(60-70 \mathrm{THI})$ while moderate heat stress ranged from $25-28{ }^{\circ} \mathrm{C}(70-85 \mathrm{THI})$ and severe heat stress occurred at $\mathrm{Ta} \geq 28$ ( $\mathrm{THI} \geq 85$ ).

\section{Effect of ambient temperature}

At zero time (before starvation), moderate heat stress (MHS) caused a significant increase in RT; meanwhile, respiratory evaporation (MV) and heat production (HP) were lower than in the TNZ. The significantly lower respiratory evaporation under MHS than in TNZ was due to an insignificant decrease in RR and TV as an adaptive mechanism to compensate the reduction in HP under heat stress (Table 2). Similar trends were found after starvation for $48 \mathrm{hrs}$ where RT was significantly higher under MHS than under TNZ, meanwhile, respiratory evaporation (RR, TV and MV) and gas exchange $\left(\mathrm{VO}_{2}\right.$ and $\left.\mathrm{VCO}_{2}\right)$ were significantly and $\mathrm{HP}$ was insignificantly lower under MHS than under TNZ. However, after starvation for $96 \mathrm{hrs,} \mathrm{MHS} \mathrm{had} \mathrm{no}$ significant effect on RT and HP, while respiratory evaporative (RR and MV) was significantly lower under MHS than under TNZ.

Khalifa et al. (2002) and Al-Haidary (2004) reported that heat stress significantly increased RT, RR and ST of sheep, while, Ismail et al. (2002) found that RT did not differ significantly between summer and winter. Meanwhile, Butswat et al. (2000) stated that an increase in respiration rate appeared to be the immediate response of sheep to environmental stress. The effect of heat stress on RT and RR depends on the severity of heat stress as indicated by Lowe et al. (2002) who reported that RR and 
RT were highly correlated with increasing THI. The insignificant changes in RR under MHS is in accordance with Srikandakumar et al. (2003) who concluded that the higher magnitude of increase in RT and lower magnitude of increase in RR in Omani sheep (local adapted breed) than in Merino ones (exogenous breed) during the period of heat stress suggests that this breed was less stressed than the Merino sheep with increasing heat stress. They suggested that this adapted breed of sheep can store body heat during the periods of heat stress, which can economize on the loss of water and the increased need of energy under these conditions.

Higher ST and lower ET under TNZ than under MHS (Table, 2) may correspond to vasodilatation under heat stress (Turnpenny et al., 1997). Khalifa (1982) and AlHaidary (2004) reported that heat stress significantly increased ST of sheep; however, Khalifa (1982) found that ET was also significantly higher in summer than in winter.

The reduction in TV under MHS is an adaptive mechanism to prevent respiratory alkalosis. Bell et al. (1983) revealed that during heat stress, panting animals increase respiratory heat loss by increasing minute ventilation (MV). When the heat stress is severe, the increase in MV includes an increase in alveolar ventilation, and consequently, arterial $\mathrm{CO}_{2}$ tension declines resulting in a respiratory alkalosis.

The insignificant decrease in HP under MHS is an adaptive mechanism to minimize the disturbance in heat balance indicated by significant increase in RT. Many authors reported that HP decreased under heat stress (Luiting et al., 1985 and Berman, 2003).

Moderate heat stress had no significant effect on RQ although the significant reduction in both of $\mathrm{VO}_{2}$ and $\mathrm{VCO}_{2}$ due to the reduction in TV under MHS (Table 2) which confirm the previous conclusion that the reduction in TV under MHS is an adaptive mechanism to prevent respiratory alkalosis.

Heat stress had no significant effect on Ht value. However, $\mathrm{Hb}$ was significantly lower under MHS than in the TNZ but the difference was insignificant after starvation for $96 \mathrm{hrs}$ due to a significant reduction in $\mathrm{Hb}$ during starvation under TNZ (Table, 3). Srikandakumar et al. (2003) reported that heat stress decreased $(P<0.01)$ $\mathrm{Hb}$ in the Merino sheep. Meanwhile, Al-Haidary (2004) reported that heat stress significantly increased Ht of Naimey sheep. Khalifa et al. (1987) indicated that the increase in $\mathrm{Ht}$ and $\mathrm{Hb}$ of sheep after exposure to solar radiation was due to the reduction in plasma volume. Accordingly, the decrease in $\mathrm{Hb}$ in the present results reveals that MHS did not affect plasma volume. The insignificant effect of heat stress on $\mathrm{Hb}$ after starvation for $96 \mathrm{hrs}$. is in accordance with Cole and Hutcheson (1985) who indicated that the degree of changes in $\mathrm{Ht}$ and $\mathrm{Hb}$ were more pronounced in ad libitum animals than in the feed-restricted animals.

Plasma TP, Alb and Gl concentrations did not differ significantly between TNZ and MHS except after starvation for $96 \mathrm{hrs}$ when plasma TP and Alb were significantly lower under MHS than under TNZ due to a significant increase in TP and Alb after starvation for $96 \mathrm{hrs}$ under TNZ. Macfarlane et al. (1959 and 1966) reported that plasma total protein of sheep changed little between summer and winter. However, Ismail et al. (2002) found that TP and Gl were higher in summer than in winter. 
Table 3. Blood parameter of Ossimi sheep as affected by Thermoneutral zone (TNZ), Moderate heat stress (MHS) and starvation conditions

\begin{tabular}{|c|c|c|c|c|c|c|c|c|c|c|c|}
\hline \multirow[t]{2}{*}{ Parameter } & \multicolumn{4}{|c|}{ Thermoneutral zone (TNZ) } & \multicolumn{4}{|c|}{ Moderate heat stress (MHS) } & \multicolumn{3}{|c|}{$\mathbf{P}$} \\
\hline & 0 time & $48 \mathrm{hr}$ & $96 \mathrm{hr}$ & S.E. & 0 time & $48 \mathrm{hr}$ & $96 \mathrm{hr}$ & S.E. & 0 time & $48 \mathrm{hr}$ & $96 \mathrm{hr}$ \\
\hline Ht $\%$ & 31.4 & 29.9 & 29.8 & 1.09 & 30.2 & 32.1 & 34.0 & 1.64 & NS & NS & NS \\
\hline $\mathrm{Hb}(\mathrm{g} / \mathrm{dl})$ & $19.1^{\mathrm{a}}$ & $20.5^{\mathrm{a}}$ & $13.1^{\mathrm{b}}$ & 0.71 & 11.3 & 12.9 & 12.5 & 0.94 & $* *$ & $* *$ & NS \\
\hline Glu. (g/dl) & 17.0 & 14.3 & 25.8 & 4.57 & $25.2^{\mathrm{b}}$ & $44.0^{\mathrm{ab}}$ & $63.8^{\mathrm{a}}$ & 12.3 & $* *$ & ** & NS \\
\hline $\operatorname{Tp}(\mathrm{g} / \mathrm{dl})$ & $6.71^{\mathrm{b}}$ & $7.87^{\mathrm{b}}$ & $10.47^{\mathrm{a}}$ & 0.53 & 7.78 & 7.52 & 7.66 & 0.39 & NS & NS & $*$ \\
\hline $\mathrm{Alb}(\mathrm{g} / \mathrm{dl})$ & $3.06^{\mathrm{b}}$ & $4.03^{\mathrm{a}}$ & $4.11^{\mathrm{a}}$ & 0.26 & 3.44 & 2.54 & 2.68 & 0.34 & NS & $* *$ & $* *$ \\
\hline $\mathrm{Gl}(\mathrm{g} / \mathrm{dl})$ & $3.65^{\mathrm{b}}$ & $3.84^{\mathrm{b}}$ & $6.36^{\mathrm{a}}$ & 0.53 & 4.34 & 4.98 & 4.98 & 0.51 & NS & NS & NS \\
\hline $\begin{array}{l}\text { Tcho. } \\
\text { (mg/dl) }\end{array}$ & 86.7 & 76.6 & 81.2 & 8.2 & 34.8 & 439 & 508 & 8.7 & $* *$ & $* *$ & $*$ \\
\hline $\mathrm{Tl}(\mathrm{g} / \mathrm{dl})$ & $4.643^{\mathrm{a}}$ & $3.253^{\mathrm{b}}$ & $3.377^{\mathrm{b}}$ & 0.32 & 2.68 & 2.51 & 2.82 & 0.29 & $* *$ & $* *$ & $* *$ \\
\hline
\end{tabular}

$\mathrm{a}, \mathrm{b}, \mathrm{c}$ similar letters within each column and variable are not significant $(\mathrm{p} \leq 0.05)$.

$\mathrm{p}=$ Probability level for the effect of ambient temperature.

$\mathrm{SE}=$ Standard error of the LEAST square means.

NS $=$ Insignificant $\mathrm{p}>0.05 . \quad *=$ Significant at $\mathrm{p} \leq 0.05 . \quad * *=$ Significant at $\mathrm{p} \leq 0.01$.

$\mathrm{Hbg} / \mathrm{l}=$ Hemoglobin concentration. $\quad \mathrm{Ht} \%=$ Hematocrite value.

$\mathrm{TP} \mathrm{mg} / \mathrm{dl}=$ Plasma total protein. $\quad \mathrm{Alb}, \mathrm{mg} / \mathrm{dl}=$ Plasma albumin.

$\mathrm{Gl} \mathrm{mg/dl} \mathrm{=} \mathrm{Plasma} \mathrm{globulin} \quad$ Glu $\mathrm{mg} / \mathrm{dl}=$ Glucose concentration

Tcho $\mathrm{mg} / \mathrm{dl}=$ Total cholesterol $\quad$ TL g/dl = Total lipids.

Plasma Glu concentration was significantly higher under MHS than under TNZ either before or after starvation for $96 \mathrm{hrs}$. Similar results were found by Samak et al. (1986) but contradict with those of Ismail et al. (2002) who reported that Glu was significantly lower in summer than in winter. Seasonal changes in Glu depend on changes in RR and HP (Shaffer et al., 1981). Opposite trends were found in plasma Tcho. and TL where they were significantly lower under MHS than under TNZ either before or after starvation (Table 3). Similar results were found by Ismail et al. (2002). The significant increase in plasma Glu concentration and decrease in plasma Tcho. and Tl under MHS agree with Srikandakumar et al. (2003) who found that heat stress increased $(P<0.01)$ plasma glucose in Merino (less adapted) but decreased $(P<0.01)$ it in Omani (more adapted) sheep. Nazifi and Gheisari (1999) found that the concentrations of serum cholesterol, triglyceride, total lipid, HDL-cholesterol, LDLcholesterol and VLDL-cholesterol of dromedary camels were significantly higher $(p<0.05)$ in winter months than in summer months. Results showed that very hot and cold conditions had a considerable effect on serum lipids in dromedaries.

The present results indicate that sheep can tolerate MHS by decreasing HP and increasing heat storage (significant increase in RT) to compensate the significant reduction in evaporative cooling (due to a decrease in TV and RR) as an adaptive mechanisms to conserve water under natural MHS. Folk (1974) stated that body temperature is naturally maintained at a relatively constant level because of the balance which exists between heat production and heat loss. Starved sheep can tolerate moderate heat stress by decreasing evaporative cooling, while normal fed sheep depend on heat storage and decrease of HP to tolerate MHS.

\section{Effect of starvation}

Starvation for 96 hrs caused a significant reduction in body weight by about $4 \%$ from the initial body weight in both seasons.

Under TNZ, starvation had no significant effect on RT, but ST and ET decreased significantly which was accompanied with significant reduction in MV due mainly to 
significant reduction in RR. The insignificant effect of starvation on RT was due to the significant reduction in both of evaporative cooling (MV) and HP (Table 2).

Under MHS, RT decreased significantly after starvation for 4 days which was accompanied with a significant reduction in evaporation due to significant reduction in RR, meanwhile starvation had no significant effect on TV and HP. On the other hand under TNZ, starvation affected significantly thermoregulation by decreasing HP and evaporative heat loss (Table 2).

The significant reduction in RT and RR after starvation for 4 days without significant effect on TV and HP indicate that starvation under MHS prevented the effect of HS on RT so that MV and RR decreased, while, HP remained almost unchanged. Piccione et al. (2002) stated that prolonged food deprivation is known to cause a fall in the core body temperature of homeotherms. Li et al. (2000) found that fasting decreased HP and RT $(\mathrm{P}<0.05)$ and Ahmed and Abdelatif (1994) stated that RT and RR were reduced by food restriction. Meanwhile, Khalifa et al. (1999a and b) found that starvation increased RT and decreased RR in both shorn and unshorn ewes under cold conditions. They explained that the significant reduction in RR of ewes in response to 2 days of starvation may be a thermoregulatory mechanism to decrease heat dissipation through panting. Finch and King (1982) attributed the reduction in RT during restriction of feed (50\% of maintenance) for 3 months to the reduction in metabolic rate and that the lower metabolic demands indicate that energy reserves could be spared from rapid depletion as starvation advances.

Under TNZ, starvation caused a significant reduction in $\mathrm{VO}_{2}, \mathrm{VCO}_{2}$ and HP (Table 2). While under MHS, starvation had no significant effect, but RQ and HP tended to decrease after starvation. Under both temperatures RQ tended to decrease with starvation due to more resuction in $\mathrm{VCO}_{2}$ than in $\mathrm{VO}_{2}$ under TNZ and an insignificant reduction in $\mathrm{VCO}_{2}$ with slight increase in $\mathrm{VO}_{2}$ under MHS. The reduction in RQ during starvation under TNZ and MHS, although it was insignificant, is in accordance with Bennet (1972) and Brockway et al. (1965) who found that the RQ declined significantly in sheep as the duration of fasting increased. Kelly et al. (1993) added that $\mathrm{O}_{2}$ consumption of ewes fed twice maintenance was higher than that of those fed maintenance ration or starved. Khalifa et al. (1999a and b) revealed that heat production, as indicated by $\mathrm{VO}_{2}$ and $\mathrm{VCO}_{2}$ changes, was significantly $(\mathrm{P}<0.05)$ decreased by starvation and duration of starvation in both shorn and unshorn ewes, reaching the lowest values at 4 days of starvation. This decrease in HP was due to the reduction in both metabolic heat production and specific dynamic action of food due to starvation. They also demonstrated that the reduction in RQ indicates that starvation caused more reduction in $\mathrm{VCO}_{2}$ than in $\mathrm{VO}_{2}$ due to catabolism of protein (RQ near 0.8 ) and fat (0.7) instead of mixed diet or carbohydrate (almost 1). As a result, after 2 days of food deprivation both shorn and unshorn ewes began to use the storage fat and body proteins as sources of energy.

Under both climatic conditions (TNZ and MHS) starvation had no significant effect on $\mathrm{Ht}$ value. Similar result was found in $\mathrm{Hb}$ under moderate heat stress, while under TNZ a significant reduction in Hb occurred after $96 \mathrm{hrs}$ of starvation (Table 3). Ali et al. (1984) reported that feed restriction for $96 \mathrm{hr}$ or $168 \mathrm{hr}$ in male Nubian goats caused a decrease in $\mathrm{Hb}$ concentration, $\mathrm{Ht}$ and erythrocytes number. Panaretto (1964) added that undernourished decreased haematocrit value by decreasing red cell volume while plasma volume remained unchanged. Under cold conditions, Khalifa et al. $(1999 \mathrm{a}, \mathrm{b})$ detected a significant $(\mathrm{P}<0.05)$ decrease in the Hb concentration 
accompanied with a non significant decrease in the Ht value in the shorn and unshorn ewes at day 4 of starvation, which indicating anemia.

Starvation had no significant effect on plasma proteins (TP, Alb and Gl) except a significant increase in TP after starvation for $96 \mathrm{hrs}$ under TNZ due to significant increase in Alb and Gl indicating that under TNZ starvation may cause a reduction in plasma volume. Similar results were found by Vihan and Rai (1984) who reported that TP values were significantly reduced in 5 days starved sheep and goats.

Under MHS starvation increased significantly plasma Glu as a source of energy to maintain HP at the pre-starvation level. While under TNZ, an insignificant increase in plasma glucose occurred after $96 \mathrm{hrs}$ of starvation (Table, 3). Rule et al. (1985) found that plasma glucose concentration in steers increased from day 2 to day 5 of fasting where it remained at this level up to day 8 of fasting. The increase in plasma glucose level during starvation may be due to the increase in growth hormone during starvation which causes the increase in glucose by its effect on gluconeogenesis. Martin (1976) stated that growth hormone secretion increases when plasma glucose levels fall during limited periods of food deprivation. The hormone promotes glucose formation from hepatic glycogen and pyruvate; it also modifies glucogenic influences of glucocorticoids.

Under TNZ, starvation caused an insignificant and significant decrease in plasma Tcho. and $\mathrm{Tl}$, respectively. Meanwhile, under MHS starvation had no significant effect on plasma Tcho. and $\mathrm{Tl}$ concentrations although plasma Tcho. Tended to decrease insignificantly during starvation (Table 3). The reduction in plasma Tcho. and Tl during starvation under TNZ disagrees with previous results of Khalifa et al (1986) who found that starvation increased significantly plasma free fatty acids and triglycerides of both shorn and unshorn ewes, while it had no significant effect on TL. Also, Cole and Hutcheson (1985 \& 1988) found that serum cholesterol was not significantly affected by feed deprivation and that serum cholesterol levels were negatively related to the feed intake of the steers.

\section{CONCLUSIONS}

The main thermoregulatory mechanisms of starved sheep under MHS are the reduction in evaporative cooling, while in normal fed sheep heat storage is the main thermoregulatory mechanism to tolerate MHS.

Sheep can tolerate MHS by decreasing HP and increasing heat storage (significant increase in RT) to compensate the significant reduction in evaporative cooling (due to a decrease in TV and RR) as an adaptive mechanisms to conserve water under natural moderate heat stress.

Under TNZ starvation had no significant effect on RT, due to a significant and insignificant reduction in heat production and evaporative cooling (MV), respectively. While under MHS, starvation reduced the effect of heat stress on RT by decreasing MV and RR, while, HP remained almost unchanged. 


\section{REFERENCES}

Ahmed, M. M. M. and A. M. Abdelatif, 1994. Effects of restriction of water and food intake on thermoregulation, food utilization and water economy in desert sheep. Journal of Arid Environments, Vol.28, No.2, pp.147-153.

Al-Haidary, A. A., 2004.Physiological responses of Naimey sheep to heat stress challenge under semi-arid environments. International Journal of Agriculture and Biology, 2004, 6, 2, 307-309.

Ali, B.W., T. Hassan and N. Musa, 1984.The effect of feed restriction on certain haematological indices enzymes and metabolites in Nubian goats. Com. Biochem. Phys. 79,325-328.

Bell, A.W., J.R.S. Hales, R.B. King and A.A. Fawcett, 1983. Influence of heat stress on exercise-induced changes in regional blood flow in sheep. J. Appl. Physiol., 55:1916-1923.

Bennett, J. W., 1972. The maximum metabolic response of sheep to cold . Effects of rectal temperature, shearing, feed consumption, body posture and body weight. Aust. J. Agric. Res. Vol. 23, 1045-1058.

Berman, A., 2003. Effects of body surface area estimates on predicted energy requirements and heat stress. Journal of Dairy Science, 86, 11, 3605-3610

Blaxter, K.L. and F.W. Wainman, 1966. The fasting metabolism of cattle. J. Nutr., 20: 103 .

Brockway, J. M., J. D. Mcdonald and J. D. Pullar, 1965. Evaporative heat-loss mechanisms in sheep. J. Physiol. Vol. 179, 544-568.

Brouwer, E., 1965. In energy metabolism (ed.) K.L. Blaxter, pp. 441-443. Proceedings of $3^{\text {rd }}$ Symposium of Energy Metabolism. London, Academic Press.

Butswat, I. S., S. T. Mbap and G. A., Ayibatonye, 2000. Heat tolerance of sheep in Bauchi, Nigeria. Tropical Agriculture, 77 , 4 , 265-268.

Cole, N.A. and D.P. Hutcheson, 1985. Influence of prefast feed intake on recovery from feed and water deprivation by beef steers. J. Anim. Sci. 60, 772-780.

Cole, N.A. and D.P. Hutcheson, 1988. Influence of protein concentration in prefast and postfast diets on feed intake of steers and nitrogen and phosphorus metabolism of Lambs. J. Anim. Sci. 66, 1764-1777.

Consolazio, C.F., R.E. Johnson and L.J. Pecora, 1963. Physiological Measurements of Metabolic Function in Man. McGraw-Hill, New York, USA.

Devendra, C.1982. Chapter 7 ( Prospects for increasing productivity from sheep and goats. in Animal Production in the Tropics, Yousef, M.K., Ed., Praeger, New York, 1982,124.

Fuquay, J.W., 1981. Heat stress as it affects animal production. J. Animal Sci. 52, 64169.

Finch, V. A. and J. M. King, 1982. "Energy-conserving mechanisms adaptation to under nutrition and water deprivation in the African Zebu." Use of tritiated water in studies of production and adaptation in ruminants. (Proc. Symp. Nirobi, 1979), IAEA, Venna (1982) 167-178.

Folk, G.E., 1974. Temperature regulation. In: Textbook of Environmental Physiology, edited by Folk, G.E. (ed) Lea and Febiger, Philadelphia, USA pp 87132. 
Ismail, E., T. A. Taha and M. A. Ayoub, 2002. Seasonal variations in body reactions, hematological and serum biochemical parameters in Barki and Awassi rams under subtropical conditions. Alexandria Journal of Agricultural Research, 47, 1, 1-16.

Johnson, D. E., C. L. Ferrell and T.G. Jenkins, 2003. The history of energetic efficiency research: Where have we been and where are we going? J. Anim. Sci. 81 (E Suppl. 1):E27-E38.

Kelly, J.M., B.G. Southorn, C.E. Kelly, L.P. Milligan, and B.W. McBride, 1993. Quantification of in vitro and in vivo energy metabolism of the gastrointestinal tract of fed or fasted sheep. Can. J. Anim. Sci. 73: 855-868.

Khalifa, H.H., 1982. Wool coat and thermoregulation in sheep under Egyptian conditions. Ph.D. Thesis, Fac. Agric., Al-Azhar Univ., Cairo, Egypt.

Khalifa H.H., H.M. Abdel-Bary, M.H. Khalil, A.A. El-Sharabassy and M.A. Safwat, 1986. Effects of starvation, seasonal variation and wool coat on free fatty acids, triglycerides and total lipids of ewe's blood plasma. $11^{\text {th }}$ International Congress for Statistics, Computer Science, Social and Demographic Research, 29 March - 3 April, 1986, pp. 451-463.

Khalifa H.H., A.A. Barghout and A.H. Barkawi, 1987. Effect of exposure to solar radiation accompanied with thirst on some physiological parameters in Ossimi, Merino and their crosses. $12^{\text {th }}$ International Congress for Statistics, Computer Science, Social and Demographic Research, 28 March - 2 April, 1987, pp. 186204.

Khalifa, H.H., E.B. Abdalla and F.A. Khalil, 1999a. Effect of starvation and shearing on thermoregulation and some blood biochemical parameters during cold season. I. In pregnant Barki sheep. $15^{\text {th }}$ International Congress of Biometeorology and International Conference on Urban Climatology, Sydney, Australia, 8-12 November.

Khalifa, H.H., F.A. Khalil and E.B. Abdalla, 1999b. Effect of starvation and shearing on thermoregulation and some blood biochemical parameters during cold season. II. In non-pregnant Barki sheep. $15^{\text {th }}$ International Congress of Biometeorology and International Conference on Urban Climatology, Sydney, Australia , 8-12 November.

Khalifa, H.H., A.A. El-Sherbiny, A. Hyder and T.M. Abdel-Khalek, 2002. Effect of exposure to solar radiation on thermoregulation of sheep and goats. Proc. the $15^{\text {th }}$ Conf. on Biometeorology and Aerobiology Joint With The $16^{\text {th }}$ International Congress on Biometeorology, Kansas City,

Khalifa, H.H., F.A. Khalil and E.B. Abdalla, 2003. Thermoregulatory mechanisms of pregnant Barki ewes to starvation and shearing during winter. Proc.of the 9th Conf.of Anim. Nut., 14-17 October, 2003.

Khalifa H.H., T.H. Shalaby and T. M. M. Abdel-Khalek, 2005. An approach to develop a biometeorological thermal discomfort index for sheep and goats under Egyptian conditions. Deutscher Wetterdienest Annalen der Meteorologie 41 volume $117^{\text {th }}$ International Congress of Biometeorology ICB2005.

Li, B.T., R. J. Christopherson and S. J. Cosgrove, 2000. Effect of water restriction and environmental temperatures on metabolic rate and physiological parameters in sheep. Canadian Journal of Animal Science, Vol.80, No.1, pp.97-104.

Lowe, T. E., N. G. Gregory, A. D. Fisher and S.R. Payne, 2002. The effects of temperature elevation and water deprivation on lamb physiology, welfare, and meat quality. Australian Journal of Agricultural Research, 53 , 6 , 707-714 . 
Luiting, P., G. Montsma, M. W. A. Verstegen, P. Hofs, W. Van der Hel and J. W. Zijlker, 1985. Effects of high ambient temperatures on the metabolism of west african dwarf goats. Int. J. Biometeor., 29, no. 1, pp. 11-22

MacFarlane, W.V., R.J.H., Morris, B. Howard and O.E. Budtz-Olsen, 1959. Extracellular fluid distribution in tropical Merino sheep. Aust. J. Agric. Res., 10: 269.

MaFarlane, W.V., B. Howard and R.J.H. Morris, 1966. Water metabolism of Merino sheep shorn during summer. Aust. J. Agric. Res., 17: 219.

Martin, C.R., 1976. Hormones and blood sugar. In Textbook of Endocrine Physiology, The Williams and Wilkins Company, Qaverly Press Inc., Baltimore, USA, pp. 107.

Mitlöhner, F. M., M. L. Galyean, J. B. Patterson, G. A. Nunnery, G. B. Salyer, J. L.Morrow-Teschb, J. W. Daileyb and J. J. McGlonea, 2001. Shade and water application to decrease heat stress of heifers in an experimental feedlot. Burnett Center Internet Progress Report, No. 10, February, 2001.

More, T., B. Howard and B.D. Siebert, 1983. Effect of level of water intake on water, energy and nitrogen balance and thyroxine secretion in sheep and goats . Aust. J. Agric. Res. 34:441-446.

Nazifi, S. and H. R. Gheisari, 1999. The influences of thermal stress on serum lipids of camel (Camelus dromedarius). J. Camel Pract. and Res., 6, No.2, pp.307-309.

NRC. 1985. Nutrient Requirements of Sheep. 6th Rev. Edn., National Academy Press, Washington, DC.

Panaretto, B. A., 1964. Body composition in vivo: VI- The composition of ewes during prolonged undernutrition . Aust. J. Agric. Res., 15: 771-787.

Piccione, G., G. Caola and R. Refinetti, 2002. Circadian modulation of starvationinduced hypothermia in sheep and goats. Chronobiol Int.2002 May;19(3):531-41.

Rule, D. C., D. C. Beitz, G. de. Boer, R.R. Lyle, A.H. Trenkle and J. W. Young, 1985. Changes in hormone and metabolite concentration in plasma of steers during a prolonged fast. J. Anim. Sci. 61, 868-875.

Salem,M.H., M.K. Yousef, A.A. El-Sherbiny and M. H. Khalil, 1982. Physiology of sheep and goats in the tropics, in Animal Production in the Tropics, Yousef, M.K., Ed., Praeger, New York, 1982,148.

Samak, M.A., G.A. Hassan, F.D. El-Nouty, Zahraa Abo Elezz and A. Badawy, 1986. Seasonal differences in some blood component of Egyptian sheep and goats. Egyptian J. Anim. Prod. 26:35-46.

SAS, 1990. Statistical Analysis System Users Guide: Statistics. SAS Inc., Caty, NC.

Shaffer, L., J. D. Roussel and K.L. Koonce, 1981. Effects of age, temperature season and breed on blood characteristics of dairy cattle. J. Dairy Sci. 64:62-70.

Srikandakumar, A., E. H. Johnson and O. Mahgoub, 2003. Effect of heat stress on respiratory rate, rectal temperature and blood chemistry in Omani and Australian Merino sheep. Small Rum. Res. , 49 , 2 , 193-198.

Thom, E. C., 1959. The Discomfort Index. Weatherwise 12:57-60.

Turnpenny,J.R., J.A. Clark, A.J. McArthur, R.W. Bottcher and S.J. Hoff1, 1997. Modelling the effect of environmental conditions on the thermal balance of the ewe. Livestock Environment 5, Volume 1. Proc.of the Fifth International Symposium, Bloomington, Minnesota, USA, 29-31 May, 1997. pp 234-241 
Vihan, V.S. and P. Rai, 1984. Studies on haematological and biochemical changes in experimental pregnancy toxaemia induced by fasting in sheep and goats. Ind. J. Vet. Med. 4: 32-36.

Yousef, M.K. and D.B. Dill, 1969. Resting energy metabolism and cardiorespiratory activity in the burro, Equus asinus. J. Appl. Physiol. 27: 229-232. 


\section{التنظيم الحرارى فى الاغنام المعرضة للتصويم والاجهاد الحرارى}

طارق محمد محمد عبد الخالق

\section{معهج بحوث الانتاج الحيوانى، وزارة النزراعة، اللدقى، الجيزة، جمهورية مصر العربية}

أجريت هذه الدراسة في محطة بحوث الانتاج الحيو انى بسخا - محافظة كفر الثيخـ معهد بحوث

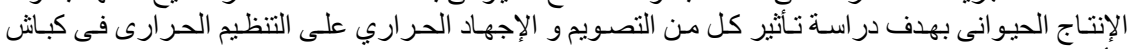

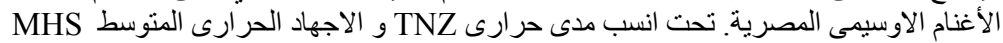

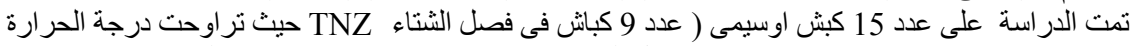

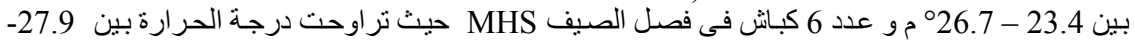

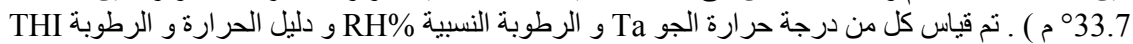

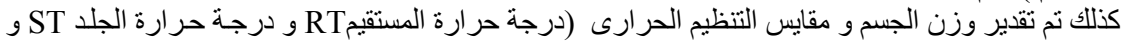

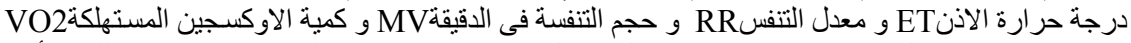

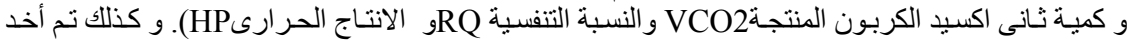

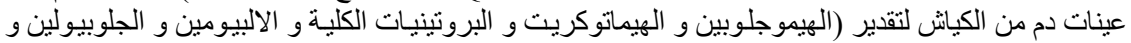

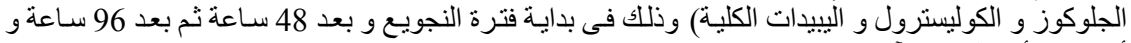

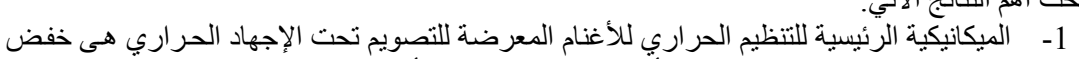

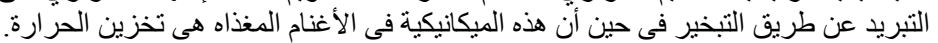

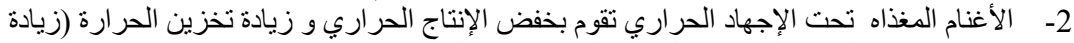

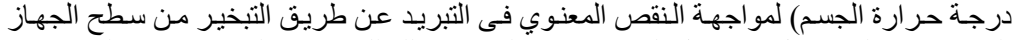

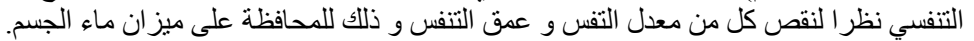

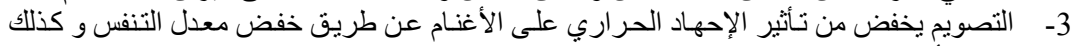
حجم الأكسجين المستهلك فى النفس دون تغيير الإنتاج الحراري. الإعن 
Egyptian J. Anim. Prod. (2007) 
Table 2. Thermoregulatory responses of Ossimi sheep under Thermoneutral zone (TNZ), Moderate heat stress (MHS) and starvation conditions

\begin{tabular}{|c|c|c|c|c|c|c|c|c|c|c|c|}
\hline \multirow[t]{2}{*}{ parameter } & \multicolumn{4}{|c|}{ Thermoneutral zone (TNZ) } & \multicolumn{4}{|c|}{ Moderate heat stress (MHS) } & \multicolumn{3}{|c|}{$\mathrm{P}$} \\
\hline & 0 time & $48 \mathrm{hrs}$ & $96 \mathrm{hrs}$ & S.E. & 0 time & $48 \mathrm{hrs}$ & $96 \mathrm{hrs}$ & S.E. & 0 time & $48 \mathrm{hrs}$ & $96 \mathrm{hrs}$ \\
\hline $\mathrm{RT}^{\circ} \mathrm{C}$ & 39.1 & 39.3 & 39.3 & 0.09 & $40.1^{\mathrm{a}}$ & $40.0^{\mathrm{a}}$ & $39.1^{\mathrm{b}}$ & 0.14 & $* *$ & $* *$ & NS \\
\hline $\mathrm{ST}^{\circ} \mathrm{C}$ & $38.0^{\mathrm{a}}$ & $37.7^{\mathrm{a}}$ & $36.3^{\mathrm{b}}$ & 0.36 & 37.6 & 36.7 & 37.4 & 0.32 & NS & $* *$ & NS \\
\hline $\mathrm{ET}^{\circ} \mathrm{C}$ & $36.3^{\mathrm{a}}$ & $33.4^{\mathrm{b}}$ & $32.7^{b}$ & 0.81 & $37.1^{\mathrm{a}}$ & $32.6^{b}$ & $33.0^{\mathrm{b}}$ & 0.34 & NS & NS & NS \\
\hline $\mathrm{RR}$ (r/min.) & 45.1 & 34.7 & 39.6 & 4.0 & $41.7^{\mathrm{a}}$ & $24.0^{b}$ & $23.0^{\mathrm{b}}$ & 2.8 & NS & $*$ & $* *$ \\
\hline TV (ml/breath) & $120^{a b}$ & $157^{\mathrm{a}}$ & $104^{\mathrm{b}}$ & 14.4 & 103 & 102 & 116 & 9.8 & NS & $*$ & NS \\
\hline MV (1/min.) & 4.529 & 4.575 & 3.461 & 0.39 & $3.278^{\mathrm{a}}$ & $2.121^{\mathrm{b}}$ & $2.254^{\mathrm{b}}$ & 0.20 & $* *$ & $* *$ & $* *$ \\
\hline $\mathrm{VO}_{2} \mathrm{~L} / \mathrm{d} . \mathrm{BW}^{0.75}$ & $5.037^{\mathrm{a}}$ & $5.327^{\mathrm{a}}$ & $3.271^{\mathrm{b}}$ & 0.87 & 3.725 & 3.725 & 3.808 & 0.36 & $* *$ & $* *$ & NS \\
\hline $\mathrm{VCO}_{2} \mathrm{~L} / \mathrm{d} \cdot \mathrm{BW}^{0.75}$ & $4.629^{\mathrm{a}}$ & $4.477^{\mathrm{a}}$ & $2.841^{\mathrm{b}}$ & 0.71 & 3.791 & 2.966 & 3.152 & 0.48 & $* *$ & $* *$ & NS \\
\hline RQratio & 0.92 & 0.84 & 0.89 & 0.06 & 1.02 & 0.80 & 0.83 & 0.08 & NS & NS & NS \\
\hline $\mathrm{HP} /$ day.BW $\mathrm{BW}^{0.75}$ & $24.2^{\mathrm{a}}$ & $25.4^{\mathrm{a}}$ & $16.6^{\mathrm{b}}$ & 2.9 & 18.0 & 18.0 & 18.9 & 1.74 & NS & NS & NS \\
\hline
\end{tabular}

$\mathrm{a}, \mathrm{b}, \mathrm{c}$ similar letters within each column and variable are not significant $(\mathrm{p} \leq 0.05)$

$\mathrm{p}=$ Probability level for the effect of ambient temperature

$\mathrm{SE}=$ Standard error of the LEAST square means.

$\mathrm{NS}=$ Insignificant $\mathrm{p}>0.05 . \quad *=$ Significant at $\mathrm{p} \leq 0.05 . \quad * *=$ Significant $\mathrm{at} \mathrm{p} \leq 0.01$.

$\mathrm{RT}{ }^{\circ} \mathrm{C}=$ Rectal temperature. $\quad \mathrm{ST}^{\circ} \mathrm{C}=$ Skin temperature. $\quad$ ET ${ }^{\circ} \mathrm{C}=$ ear temperature

$\mathrm{RR} \mathrm{r} / \mathrm{min} .=$ Respiration rate. $\quad$ MV $1 /$ minute $=$ Respiratory minute volume

$\mathrm{TV}(\mathrm{ml} /$ breath $)=$ Tidal volume

HP $/$ day $\mathrm{BW}^{0.75}=$ Heat production.

$\mathrm{VO}_{2} \mathrm{~L} / \mathrm{d} . \mathrm{BW} \mathrm{W}^{0.75}=$ Oxygen consumption.

$\mathrm{VCO}_{2} \mathrm{~L} / \mathrm{d} \cdot \mathrm{BW}^{0.75}=$ carbon dioxide production

RQratio $=$ Respiratory Quotient. 